\title{
MAGGOT BLACK SOLDIER FLY SEBAGAI AGEN DEGRADASI SAMPAH ORGANIK DAN PAKAN TERNAK WARGA MERGANGSAN YOGYAKARTA
}

\section{BLACK SOLDIER FLY LARVA AS DEGRADATION AGENTS OF ORGANIC WASTE AND ANIMAL FEED IN MERGANGSAN SUB-DISTRICT, YOGYAKARTA}

\author{
Inggita Utami $^{1 *}$, Ichsan Luqmana Indra Putra ${ }^{1)}$, Khusnul Khotimah ${ }^{1)}$, Rizki G. \\ Pangestu ${ }^{1)}$
}

\author{
${ }^{1)}$ Program Studi Biologi, Fakultas Sains dan Teknologi Terapan, Universitas Ahmad Dahlan \\ email: inggitautami@bio.uad.ac.id
}

\begin{abstract}
ABSTRAK
Enam puluh persen sampah yang dihasilkan di Indonesia masih berupa sampah organik. Maggot atau larva black soldier fly-BSF (Hermetia illucens L.) mulai digunakan sebagai agen biologis pendegradasi sampah organik. Maggot terkenal kaya protein sehingga dapat dijadikan alternatif pakan bagi warga Mergangsan yang banyak membudidayakan lele cendol. Tujuan pengabdian kepada masyarakat ini adalah memberikan penyuluhan dan pelatihan dalam memanfaatkan maggot bagi warga Kecamatan Mergangsan Kota Yogyakarta. Kegiatan ini dilakukan pada bulan Juni hingga September 2020 kepada mitra yaitu anggota Pimpinan Cabang Aisyiyah (PCA) Mergangsang Yogyakarta. Paska penyuluhan dan pelatihan ini terjadi peningkatan dari $24 \%$ menjadi $100 \%$ peserta yang mengolah sampah organik rumah tangganya dengan ember tumpuk dan maggot. Peserta yang semula tidak paham dengan bentuk dan manfaat maggot menjadi paham paska pelatihan tatap muka. Perpaduan ember tumpuk dan maggot pada kegiatan ini dijadikan sebagai teknologi tepat guna dalam mendegradasi sampah organik dan memisahkan air lindi yang dapat diolah menjadi pupuk cair organik.
\end{abstract}

Kata kunci: Maggot, Bsf, Sampah, Pakan, Yogyakarta

\section{ABSTRACT}

Sixty percent of the waste produced in Indonesia is still organic waste. Maggot or black soldier fly-BSF larvae (Hermetia illucens L.) began to be used as a biological agent for degrading organic waste. Maggot is also known to be rich in protein so it can be used as an alternative feed for Mergangsan residents who cultivate catfish. The aim of this community service is to provide counseling and training in utilizing maggot for residents of Mergangsan District, Yogyakarta City. This activity was carried out from June to September 2020 for partners, namely members of Pimpinan Cabang Aisyiyah (PCA) Mergangsang Yogyakarta. After this counseling and training, there was an increase from $24 \%$ to $100 \%$ of participants who processed their household organic waste with stacked buckets and maggots. Participants who initially did not understand the form and benefits of maggot became understand after face-to-face training. The combination of stacked buckets and maggot in this activity is used as an appropriate technology in degrading organic waste and separating leachate which can be processed into organic liquid fertilizer.

Keywords: Maggot, Bsf, Waste, Feed, Yogyakarta

\section{PENDAHULUAN}

Indonesia merupakan negara dengan Menurut Kementerian Lingkungan Hidup penduduk terbesar keempat di dunia yang dan Kehutanan (KLHK), $60 \%$ sampah di berakibat pada tingginya produksi sampah Indonesia merupakan sampah organik yang [1] [2]. Kota besar di Indonesia umumnya tercampur dengan sampah anorganik [3]. 
Akibat pencampuran tersebut, pembusukan sulit terjadi dengan sempurna dan produksi gas methan sangat tinggi [4]. Setiap hari rata-rata $800-2.000$ ton sampah masuk ke Tempat Pembuangan Akhir (TPA) [5] Ironisnya $90 \%$ TPA di Indonesia masih open dumping yang tinggi akan produksi air lindi yang mencemari tanah. Kota Yogyakarta sebagai kota terpadat keenam di Indonesia [6] juga menghadapi masalah dalam pengolahan sampahnya. Tumpukan sampah di TPA Piyungan, Bantul kini mencapai 60 meter dengan 50\% pasokan sampah berasal dari Kota Yogyakarta [7].

Salah satu inovasi alami yang mulai digunakan untuk mendegradasi sampah organik adalah maggot [8]. Maggot merupakan fase larva dari lalat tentara hitam atau black soldier fly-BSF (Hermetia illucens L., 1758) (Gambar 1) yang termasuk dalam bangsa diptera, suku stratiomyidae [9]. Larva BSF terdiri dari 6 tahap instar. Lalat ini dapat ditemui di seluruh dunia yang wilayahnya beriklim tropis dan subtropis. BSF bukan merupakan hama dan tidak dijumpai pada pemukiman [10]. Siklus hidup BSF dari telur hingga menjadi lalat dewasa sekitar 40 hingga 43 hari, tergantung dari kondisi lingkungan dan media pakan yang diberikan [11]. Ikan nila yang diberi pakan tambahan maggot BSF menunjukkan pertumbuhan yang lebih cepat dan lebih berat [12] [13]. Kandungan protein pada maggot sekitar 44,26 \% dan kandungan lemaknya sebesar 29,65\% [14]. Maggot juga

mengandung antimikroba dan anti jamur yang relatif tinggi, sehingga apabila dijadikan pakan tambahan akan membuat ikan tahan terhadap penyakit yang disebabkan oleh jamur atau mikroba [15].

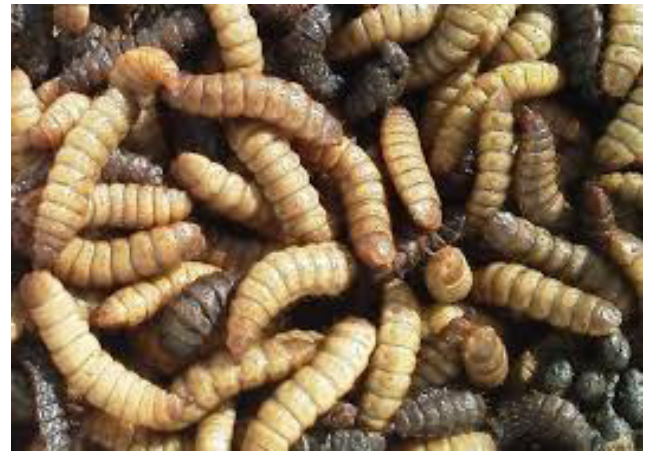

Gambar 1. Maggot BSF instar 5 dan 6

Beberapa Warga Brontokusuman di Kecamatan Mergangsan Yogyakarta membudidayakan lele cendol dengan pengeluaran rutin salah satunya untuk biaya pakan. Biaya pakan menjadi pengeluaran tersebesar bagi para pembudidaya ikan yaitu berkisar $50 \%$ hingga $70 \%$ dari total pengeluaran [16]. Melalui pemanfaatan maggot dalam mendegradasi sampah organik diharapkan dapat meningkatkan pengetahuan dan keterampilan warga Brontokusuman Mergangsan dalam mengolah sampah ditingkat rumah tangga dan menggunakan maggot menjadi alternatif pakan ternak lele yang kaya protein. Tujuan pengabdian kepada masyarakat ini adalah memberikan penyuluhan dan pelatihan pemanfaatan maggot bagi warga Kecamatan Mergangsan Kota Yogyakarta. 
METODE PELAKSANAAN KEGIATAN

Tahapan Kegiatan

Kegiatan pengabdian kepada masyarakat ini terdiri dari beberapa tahapan yaitu survey dan persiapan kegiatan di bulan Juni 2020, penyuluhan budidaya maggot secara daring pada tanggal 11 dan 12 Juli 2020, serta pelatihan secara tatap muka pada tanggal 29 Agustus 2020 yang terdiri dari pelatihan bin budidaya maggot di kandang, pengomposan sampah organik dengan ember tumpuk, dar penjemuran air lindi menjadi pupuk cair kuesioner yang sama sebagai penilaian organik sebagai produk samping dari keberhasilan kegiatan pengabdian kepada pengomposan dengan ember tumpuk, dan masyarakat ini (Tabel 1). Kuesioner berisi 8 pengeringan maggot. Penyuluhan dilakukan soal yang berkaitan dengan maggot dan secara daring mengingat kondisi pandemi pemanfaatannya. Peserta dapat mengisi lima Covid-19 yang mewajibkan masyarakat pilihan jawaban yaitu tidak paham (skor 1), tidak melakukan aktifitas massal terlebih kurang paham (skor 2), cukup paham (skor dahulu. Pada pelatihan tatap muka peserta 3), paham (skor 4), sangat paham (skor 5). yang mengikuti kegiatan diwajibkan Analisis data dilakukan secara kuantitatif mengikuti protokol kesehatan dengan dan kualitatif. Kuesioner sebelum dan melakukan cuci tangan dan menggunakan setelah penyuluhan, serta kuesioner sebelum masker. Selanjutnya selama bulan dan setelah pelatihan tatap muka dianalisis Sepetember 2020 dilakukan monitoring dengan uji statistik untuk dua kelompok data kegiatan.

Pengumpulan dan Analisis Data Kegiatan aplikasi SPSS 16 dengan terlebih dahulu

Terdapat 21 peserta dimana $81 \%$ melakukan uji normalitas dan homogenitas termasuk anggota Pimpinan Cabang [18]. Selain itu, manfaat lain dari kegiatan Aisyiyah (PCA) Mergangsan Yogyakarta. ini dijelaskan secara deskriptif. Sebanyak $76 \%$ dari total peserta merupakan
[17]. Uji statistik dilakukan menggunakan 


\begin{tabular}{|l|l|l|l|l|l|l|}
\hline \multicolumn{2}{|l|}{ Apakah bapa/ibu memahami hal berikut : } & $\begin{array}{c}\text { Tidak } \\
\text { Paham }\end{array}$ & $\begin{array}{c}\text { Kurang } \\
\text { Paham }\end{array}$ & $\begin{array}{l}\text { Cukup } \\
\text { Paham }\end{array}$ & Paham & $\begin{array}{c}\text { Sangat } \\
\text { Paham }\end{array}$ \\
\hline 1 & Cara mengompos sampah organik? & & & & & \\
\hline 2 & Bentuk maggot? & & & & & \\
\hline 3 & $\begin{array}{l}\text { Maggot berfungsi untuk mengurangi } \\
\text { sampah organik? }\end{array}$ & & & & \\
\hline 4 & Budidaya maggot? & & & & & \\
\hline 5 & $\begin{array}{l}\text { Maggot memiliki protein yang tinggi } \\
\text { sebagai pakan ternak? }\end{array}$ & & & & & \\
\hline 6 & Cara mengeringkan maggot? & & & & & \\
\hline 7 & $\begin{array}{l}\text { Mengolah sampah praktis menggunakan } \\
\text { drum tumpuk? }\end{array}$ & & & & & \\
\hline 8 & $\begin{array}{l}\text { Air lindi yang dijemur dapat menjadi } \\
\text { pupuk cair organik }\end{array}$ & & & & & \\
\hline
\end{tabular}

HASIL DAN PEMBAHASAN

Pelaksanaan kegiatan pengabdian kepada masyarakat dinilai meningkatkan kesadaran dan minat peserta untuk mengompos dan mengolah sampah organik rumah tangganya. Sebelum Penyuluhan Daring penyuluhan dan pelatihan dilaksanakan, baru $24 \%$ peserta yang sudah melakukan sebagai agen biologis pengurai sampah pengomposan. Paska pelatihan diketahui organik dan alternatif pakan ternak sudah $100 \%$ peserta yang mengompos dan mengalami peningkatan paska penyuluhan mengolah sampah organik rumah tangganya dan pelatihan. Hasil uji wilcoxon untuk dua dengan bantuan maggot. Walaupun peserta kelompok berpasangan menunjukan nilai banyak diantaranya sebagai pengurus bank significant (2-tailed) sebesar 0,00 $(<0,05)$ sampah, tetapi diantara mereka hanya fokus atau berbeda nyata [19]. Hal tersebut mengolah sampah anorganik seperti botol menunjukan bahwa penyuluhan daring plastik dan plastik kemasan bekas. Drum memberikan pengaruh terhadap komposter yang pernah diberikan ke setiap pengetahuan, pemahaman, dan keterampilan pengurus bank sampah oleh Dinas peserta mengenai pengolahan sampah Lingkungan Hidup (DLH) Kota Yogyakarta organik dan manfaat maggot. Hasil dinilai kurang praktis dan lama dalam pengisian kuesioner setelah penyuluhan melakukan pengomposan. Berdasarkan daring menunjukan adanya peningkatan alasan tersebut, banyak pengurus bank pengetahuan dari yang semula rata-rata sampah di Kecamatan Mergangsan yang "tidak paham" menjadi “cukup paham”. 
Penyuluhan secara daring memanfaatkan adalah Inggita Utami, M.Sc. dan Ichsan aplikasi zoom untuk memberikan rekaman Luqmana I.P., M.Si., dosen Biologi suara pada materi powerpoint (Gambar 2). Universitas Ahmad Dahlan (UAD). Inggita Materi yang diberikan selama penyuluhan Utami adalah dosen dibidang ekologi dan daring meliputi:

1. Siklus hidup lalat tentara hitam

2. Ciri morfologi maggot

3. Pemeliharaan maggot di kandang

4. Pembuatan pelet maggot

5. Ember tumpuk untuk proses pengolahan sampah organik

6. Pemanenan maggot dan air lindi

7. Pembuatan pupuk cair organik dari air lindi

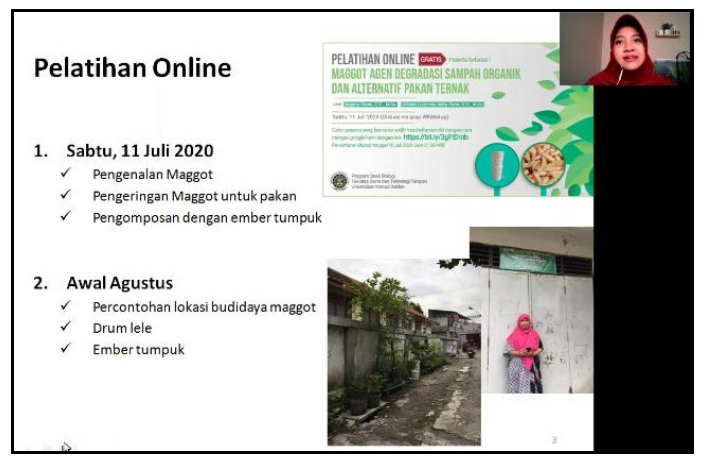

Gambar 2. Penyampaian Materi Secara

Daring (Dokumen pribadi, 2020)

Diskusi selama penyuluhan dilakukan menggunakan aplikasi whatsapp group. Aplikasi tersebut digunakan setelah melakukan survey kepada peserta yang mayoritas adalah ibu rumah tangga dan mayoritas memiliki aplikasi whatsapp di smartphonenya. Paska menyampaikan materi, peserta aktif bertanya dan menyampaikan pengalaman mereka berinteraksi dengan maggot. Pemberian materi dan diskusi menggunakan media whatsapp group dilakukan penuh selama dua hari (Gambar 3). Narasumber kegiatan ini lingkungan yang telah beberapa kali memberikan penyuluhan dan pelatihan ember tumpuk dan maggot kepada anggota Aisyiyah di Provinsi D.I. Yogyakarta. Ichsan Luqmana adalah dosen dibidang entomologi yang sedang melakukan riset pengaruh pakan pelet maggot terhadap pertumbuhan ikan lele. Selama kegiatan berlangsung terdapat dua mahasiswa program studi biologi turut terlibat dalam diskusi. Kedua mahasiswa tersebut berpengalaman dengan maggot saat Kuliah Kerja Nyata (KKN). Kerjasama tim yang telah memiliki rekam jejak dengan pemanfaatan maggot membuat diskusi dengan peserta menjadi lebih interaktif dan kaya informasi.

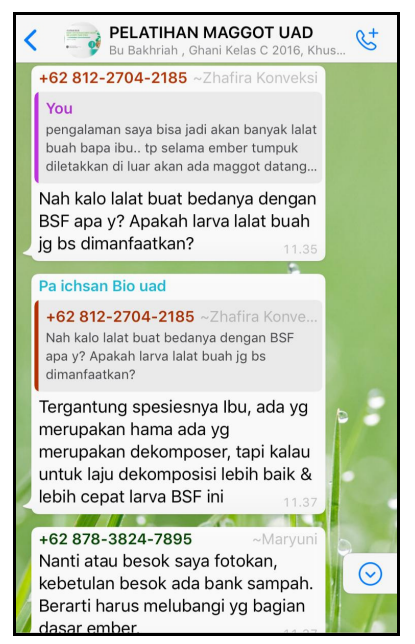

Gambar 3. Diskusi via whatsapp group

Penyuluhan secara daring dinilai cukup berpengaruh positif terhadap peningkatan pengetahuan peserta, tetapi untuk peningkatan keterampilan dinilai masih kurang berpengaruh. Sebanyak $81 \%$ peserta 
menjawab "kurang paham" pada pertanyaan muka menunjukan adanya peningkatan yang teknis seperti bentuk maggot, cara yang semula rata-rata menjawab "tidak mengeringkan maggot, budidaya maggot dan paham" menjadi "paham". Sebanyak $81 \%$ pengolahan sampah dengan ember tumpuk. yang semula menjawab "kurang paham" Tampilan materi yang pasif tanpa adanya paska penyuluhan daring dalam pertanyaan praktik langsung di lapangan membuat teknis mulai beralih menjadi "paham" dan kegiatan pengabdian masyarakat secara "sangat paham".

daring dan asinkron mengalami kendala. Peserta yang pada umumnya berprofesi sebagai ibu rumah tangga tidak pernah melakukan diskusi daring sinkron sehingga panitia memutuskan untuk melakukan perekaman materi. Keterbatasan tersebut telah diantisipasi dengan memberikan video yang informatif tetapi ternyata belum mampu meningkatkan keterampilan peserta.

\section{Pelatihan Tatap Muka}

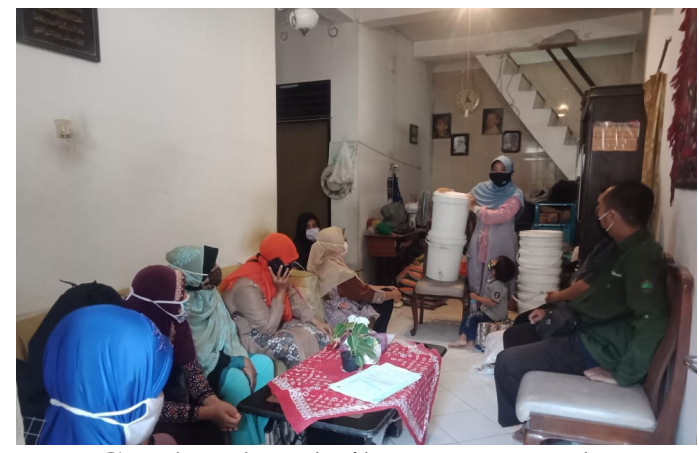

Gambar 4. Pelatihan Tatap Muka Pengenalan Ember Tumpuk

Pelatihan secara tatap muka dinilai peserta lebih efektif dengan tingkat kepuasan

Pelatihan tatap muka mengenai pelatihan sebesar $100 \%$ dibandingkan penggunaan ember tumpuk (Gambar 4), penyuluhan secara daring yang hanya budidaya maggot di kandang, serta sebesar 43\%. Peserta dapat melihat fisik pengeringan maggot untuk pakan dilakukan ember tumpuk yang digunakan untuk pada akhir Agustus 2020. Hasil uji statistik membuang sampah organik. Peserta juga menunjukan bahwa data tidak terdistribusi dapat melihat contoh kandang maggot yang normal dan homogen sehingga perlu digunakan untuk budidaya BSF. Maggot melanjutkan dengan uji non parametrik [17]. instar 1 dan 2 yang berperan utama dalam Hasil uji wilcoxon antara sebelum dan pelatihan ini juga dihadirkan dan dibagikan setelah pelatihan tatap muka menunjukan ke peserta. Peserta aktif dan antusias dalam nilai significant sebesar $0,00(<0,05)$ atau mengajukan pertanyaan dan pengalamannya berbeda nyata [19]. Hasil tersebut berinteraksi dengan maggot. Umumnya menunjukan bahwa pelatihan tatap muka peserta mengatakan sering melihat maggot berpengaruh terhadap peningkatan yang mereka kenal dengan belatung dan pengetahuan, pemahaman, dan keterampilan menganggap hewan tersebut adalah hama. peserta mengenai pengolahan sampah Paska penyuluhan dan pelatihan ini peserta organik dan manfaat maggot. Hasil menjadi paham asal usul maggot dan pengisian kuesioner setelah pelatihan tatap manfaatnya bagi kehidupan sehari-hari. 


\section{Monitoring}

Kondisi pandemi covid-19 yang masih melanda di Kota Yogyakarta hingga September 2020 membuat kegiatan selc monitoring dioptimalkan melalui aplikasi whatsapp group. Peserta aktif mengabarkan kondisi ember tumpuk yang sudah berisi lemak paling tinggi dibandingkan tingkatan sampah organik rumah tangga dan maggot. instar sebelumnya [16]. Pengenalan maggot Perbedaan sampah organik yang dibuang dan kepada masyarakat khususnya yang lingkungan di rumah masing-masing peserta memiliki hewan ternak dinilai penting membuat adanya variasi perkembangan karena pemberian pakan maggot akan maggot. Peserta umumnya mengirimkan menghemat biaya pakan [20]. Harapannya video dan penjelasan mengenai sampah yang warga Mergangsan akan memanfaatkan dibuang dan aktifitas maggot didalamnya maggot tidak hanya sebagai alternatif pakan, (Gambar 5). Warga yang memiliki ternak tetapi juga untuk mengolah sampah organik ayam dan lele menceritakan bahwa maggot skala rumah tangga. Ember tumpuk yang yang melimpah di dalam ember tumpuk didesain untuk menyaring air lindi dapat dapat diberikan langsung ke ternak mereka. dimanfaatkan warga sebagai pupuk cair Harapan warga nantinya biaya pakan pelet organik paska di jemur hingga tidak berbau yang biasa dikeluarkan setiap bulan akan [21]. Tujuan akhir dari kegiatan ini adalah berkurang seiring dengan beralihnya adanya transfer ilmu dan teknologi tepat pemberian maggot segar maupun yang sudah dikeringkan.

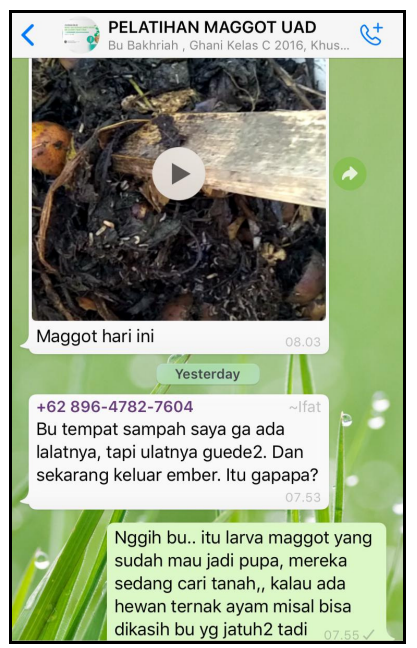

Gambar 5. Monitoring Whatsapp Group

Tiga minggu paska pelatihan tatap muka umumnya maggot sudah memasuki instar 6 guna dengan memanfaatkan agen biologis yang gratis di alam kepada warga untuk meningkatkan nilai ekonomis. Nilai ekonomis dapat difokuskan pada maggot yang dapat dijadikan alternatif pakan dan air lindi yang dapat dijadikan pupuk cair organik.

\section{KESIMPULAN}

Kegiatan pengabdian kepada masyarakat ini dilakukan baik secara daring maupun tatap muka dengan menerapkan standar pencegahan covid-19. Pelatihan tatap muka dinilai lebih efektif daripada penyuluhan daring dengan mayoritas peserta menyatakan 
paham dengan materi yang disampaikan. saja tetapi juga seluruh kecamatan di Kota Hasil uji statistik juga menunjukan bahwa Yogyakarta. Selain itu lembaga penyuluhan daring hingga pelatihan tatap pemerintahan terkait seperti Dinas muka memberikan pengaruh terhadap Lingkungan Hidup (DLH) Kota Yogyakarta pemahaman dan keterampilan warga dalam dapat membantu warga dalam memanfaatkan maggot. Seluruh peserta puas memperkenalkan maggot ini sebagai agen terhadap pelatihan tatap muka yang biologis pengolah sampah organik dan diberikan dan langsung menerapkan hasil alternatif pakan ternak.

pelatihan dalam kehidupan sehari-hari.

Seluruh peserta mulai mengolah sampah organik dengan ember tumpuk dan maggot serta melaporkan dalam whatsapp group. Perpaduan ember tumpuk, maggot, dan pupuk cair organik lindi pada kegiatan ini dijadikan sebagai teknologi tepat guna dalam mendegradasi sampah organik dan meingkatkan nilai ekonomi sampah.

\section{SARAN}

Kegiatan pengenalan maggot kepada masyarakat kini dirasa penting dan mendesak mengingat kondisi Tempat Pembuangan Akhir (TPA) Piyungan sudah sangat melebihi daya tampungnya. Warga di Kota Yogyakarta sebagai penyumbang 50\% sampah ke TPA Piyungan setiap harinya wajib diberikan solusi dan edukasi untuk dapat mengurangi, mengolah, dan memakai ulang sampah yang dihasilkan agar menjadi sesuatu yang bermanfaat kembali. Sampah organik sebagai penyumbang gas methan dan gas rumah kaca harus terus diolah dan maggot ini dapat dijadikan solusi yang murah dan ramah lingkungan. Harapannya penyuluhan dan pelatihan ini tidak hanya dalam lingkup di Kecamatan Mergangsan

\section{UCAPAN TERIMAKASIH}

Terima kasih kepada LPPM Universitas Ahmad Dahlan atas bantuan pendanaan dan moril selama kegiatan ini berlangsung. Terima kasih juga diucapkan kepada Ketua Pinpinan Cabang Aisyiyah Mergangsan atas kerjasamanya sehingga anggotanya dapat berpartisipasi dalam kegiatan ini.

\section{REFERENSI}

[1] Worldometers. 2020. World Population. (https://www.worldometers.info/worldpopulation/ diakses 10 September 2020).

[2] Satiti, S. 2019. Gerakan Ayo Sekolah di Kabupaten Bojonegoro: Peningkatan Sumber Daya Manusia melalui Pendidikan untuk Menyongsong Bonus Demografi. Jurnal Kependudukan Indonesia, 14(1), 77-92.

[3] KLHK. 2017. Statistik Lingkungan Hidup Indonesia (SLHI) 2017. Jakarta: KLHK.

[4] Monita, L., Sutjahjo, S. H., Amin, A. A., \& Fahmi, M. R. 2017. Pengolahan Sampah Organik Perkotaan Menggunakan Larva Black Soldier Fly (Hermetia illucens). Jurnal Pengolahan Sumberdaya Alam dan Lingkungan, 7(3), 227-234.

[5] Kompas. 2018. TPA Piyungan Ditutup Warga. Terbit cetak tanggal 30 November 2018.

[6] Setda DIY. 2020.. Penduduk Kota Yogyakarta. 
(https://kependudukan.jogjaprov.go.id/ olah.php? module $=$ statistik $\&$ periode $=1$ $3 \&$ jenisdata $=$ penduduk \&berdasarkan $=\mathrm{j}$ umlahpenduduk \&prop $=34 \& \mathrm{kab}=71 \& \mathrm{k}$ ec $=06$ diakses tanggal 12 Februari 2020).

[7] Kompas. 2019. TPST Piyungan

Ditutup, Sampah di Beberapa Yogyakarta Menumpuk. Terbit cetak tanggal 27 Maret 2019.

[8] Dortmans, B., Diener, S., Versstappen, B., \& Zurbrugg, C. 2017. Proses Pengolahan Sampah Organik dengan Black Soldier Fly (BSF). Alih bahasa oleh Dwi Cahyani Octavianti. Swiss: Eawag.

[9] Nguyen, T., Tomberlin, J., \& Vanlaerhoven, S. 2015. Ability of black soldier fly (Diptera: Stratiomyidae) Larvae to Recycle Food Waste. Environmental Entomology, 44(2), 406-410.

[10]Li, Q., Zheng, L., Qiu, N., Cai, H., Tomberlin, J., \& Yu, Z. 2011. Bioconversion of Dairy Manure by Black Soldier Fly (Diptera: Stratiomyidae) for Biodiesel and Sugar Production. Waste Management, 31(6), 1316-1320.

[11] Tomberlin, J., Sheppard, D., \& Joyce, J. 2002. Selected life-history traits of Black Soldier Flies (Diptera: Stratiomyidae) reared on three artificial diets. Ann Entomol Soc Am, 95(3), 379-386.

[12]Wang, Y., \& Shelomi, M. 2017. Review of black soldier fly (Hermetia illucens) as animal feed and human food. Foods, 6(91), 1-23.

[13] Stamer, A., Wesselss, S., Neidigk, R., \& Hoerstgen-Schwark, G. 2017. Black soldier fly (Hermetia illucens) larvae- meal as an example for a new feed ingredients' class in aquaculture diets. The 4th ISOFAR Scientific Conference, Istanbul. (pp. 13-15).

[14]Fahmi, M., Hem, S., \& Subamia, I. 2007. Potensi Maggot sebagai Salah Satu Sumber Protein Pakan Ikan. Dalam Dukungan Teknologi untuk Meningkatkan Produk Pangan Hewan dalam Rangka Pemenuhan Gizi Masyarakat dan Seminar Nasional Hari Pangan Sedunia 27. 21 November $2007 . \quad$ Bogor: Puslitbangnak.

[15] Wardhana, A. H. 2017. Black soldier fly (Hermetia illucens) sebagai sumber protein alternatif untuk pakan ternak. Indonesian Bulletin of Animal and Veterinary Science, 26(2), 69-78.

[16]Mokolensang, J. F., Hariawan, M. G., \& Manu, L. 2018. Maggot (Hermetia illunces) sebagai pakan alternatif pada budidaya ikan. Budidaya Perairan, 6(3), 32-37.

[17]Utami, I., \& Putra, I. L. 2020. Ekologi Kuantitatif; Metode Sampling dan Analisis Data Lingkungan. Yogyakarta: K-Media.

[18]Trihendradi, C. 2009. Step By Step SPSS 16 Analisis Data Statistik. Yogyakarta: Penerbit ANDI.

[19]Hadi, S. 2017. Statistik (Edisi Revisi). Yogyakarta: Pustaka Pelajar.

[20]Fauzi, R. U., \& Sari, E. R. 2018. Analisis Usaha Budidaya Maggot sebagai Alternatif Pakan Lele. Industria: Jurnal Teknologi dan Manajemen Agroindustri, 7(1), 39-46.

[21]Alattar, M. 2012. Biological Treatment of leachates of microaerobic fermentation. Thesis tidak diterbitkan, Portland: Portland State University. 